\title{
Adenosine Triphosphatase Activity and its Sensitivity to Ruthenium Red Oscillate during the Cell Cycle of Escherichia coli K12
}

\author{
By ROBERT I. SCOTT, JANE F. GIBSON AND \\ ROBERT K. POOLE* \\ Department of Microbiology, Queen Elizabeth College, University of London, \\ Campden Hill, London W8 7 AH
}

(Received 29 January 1980; revised 31 March 1980)

\begin{abstract}
A procedure has been developed for the large-scale fractionation into size and age classes of bacteria from exponentially growing cultures of Escherichia coli $\mathrm{K} 12$ by centrifugation through an equivolumetric gradient of sucrose in a zonal rotor. The resolution attained is superior to that in methods of this type that have been described previously. The activity of adenosine triphosphatase (ATPase) was assayed in extracts from bacteria separated into size classes by this method and from synchronous cultures prepared by size selection. Activity approximately doubled during a cell cycle, but the experimental data did not fit models of either continuously or exponentially increasing activity during the cycle. It is suggested that ATPase activity oscillates during the cell cycle with maxima at about 0.37 and 0.80 of a cycle. The fluctuations in activity greatly exceed the variations due to experimental error and, in the case of synchronous cultures, do not arise from perturbations in growth behaviour following zonal gradient selection. Sensitivity of ATPase activity to $75 \mu \mathrm{M}-$ Ruthenium Red also fluctuates during the cell cycle, with maximum inhibition ( 60 to $80 \%$ ) occurring near the middle of the cycle, a time that does not coincide with maximum enzyme activity.
\end{abstract}

\section{INTRODUCTION}

Under conditions of balanced growth, a bacterium must duplicate every cellular constituent during its cell cycle. Certain events are periodic, such as the initiation of chromosomal DNA synthesis, nucleoid segregation and septation (Donachie, 1979). Measurements of the synthesis of membrane-associated components and of the development of respiratory activity during the cell cycle have given conflicting results (for review, see Poole, 1980). When rates of synthesis of total, or soluble, protein and membrane protein have been carefully studied in the same experiment (Sargent, 1973; Churchward \& Holland, 1976), only the latter have been found to be discontinuous. In a recent study by Lutkenhaus et al. (1979), the pattern of synthesis of about 750 individual polypeptides was followed through the cell cycle of Escherichia coli and no protein could be identified that was synthesized at different rates at different stages of the cycle.

However, when enzyme activities, rather than rates of protein synthesis, have been measured, many show discontinuous patterns through the cell cycle. A stepwise increase in activity has been demonstrated for various dehydrogenases in several bacteria (Sargent, 1973; Ohki \& Mitsui, 1974; Hartmann et al., 1977; Wraight et al., 1978). In contrast, marked oscillations in adenosine triphosphatase (ATPase) activity have been observed by Edwards ct al. (1978) during growth of Alcaligenes eutrophus synchronized by a continuous-flow 
selection technique. Maximum activities were observed at about 0.4 and 0.9 of a cycle coinciding with maximum sensitivity of the enzyme to inhibition by 4-chloro-7-nitrobenzofurazan, minimum sensitivity to $N, N^{\prime}$-dicyclohexylcarbodiimide and maximum rates of oxygen uptake (Edwards \& Jones, 1977). In none of the above cases of discontinuous increase in enzyme activity were control experiments conducted to demonstrate that the observed discontinuities were related to the unperturbed cell cycle and did not result from the synchronization procedure. Perturbations in the pattern of increase in enzyme activity (Mitchison, 1977) and leucine incorporation (Creanor \& Mitchison, 1979) have been shown to result from use of the density gradient centrifugation method for preparing synchronous cultures of yeast.

In this paper, we have examined the ATPase of $E$. coli and used two independent methods of cell cycle analysis to demonstrate that the activity of this enzyme does not increase continuously during the cell cycle.

\section{METHODS}

Organism and growth conditions. Escherichia coli K12 (strain A1002) was grown as previously described (Poole et al., 1979) except that casein hydrolysate was omitted and the concentrations of isoleucine, valine and methionine were each increased to $1 \mathrm{mg} \mathrm{ml}^{-1}$. Stocks were maintained by adding sterile glycerol to a portion $(2 \mathrm{ml})$ of a stationary phase culture to give a final concentration of $12.5 \%(\mathrm{w} / \mathrm{v})$ and storing at $-20^{\circ} \mathrm{C}$. Starter cultures, $20 \mathrm{ml}$ medium in $250 \mathrm{ml}$ Erlenmeyer flasks, were inoculated with a drop of thawed stock culture and shaken at $200 \mathrm{rev}$. $\mathrm{min}^{-1}$ at $37^{\circ} \mathrm{C}$ for about $12 \mathrm{~h}$. Approx. $5 \mathrm{ml}$ of starter culture was inoculated into 41 of the same medium in a Gallenkamp $\mathrm{CeCa}$ fermenter vessel maintained at $37^{\circ} \mathrm{C}$ and stirred at $1100 \mathrm{rev} . \mathrm{min}^{-1}$. Air was passed into the head space above the culture $\left(41 \mathrm{~min}^{-1}\right)$. Under these conditions, the $\mathrm{O}_{2}$ transfer rate $\left(K_{\mathrm{L}} a\right)$ measured in the absence of biomass using sodium sulphite with $\mathrm{Cu}^{2+}$ as catalyst (Pirt, 1975) was $54 \cdot 2 \mathrm{mmol} \mathrm{l}^{-1} \mathrm{~h}^{-1}$. Cells were harvested towards the end of exponential growth when the absorbance $\left(A_{600}\right)$, measured in cuvettes of $1 \mathrm{~cm}$ path length in a Pye Unicam SP1700 spectrophotometer, was about 0.7 and the cell count was approx. $2 \times 10^{\circ}$ organisms $\mathrm{ml}^{-1}$.

Selection of size classes from asynchronous populations by zonal centrifugation. The separation of cells into size classes by centrifugation was accomplished in equivolumetric sucrose gradients (Pollack \& Price, 1971). Gradient profiles were computed, using a CDC 6600 computer, for use at $4^{\circ} \mathrm{C}$ in an MSE HS zonal rotor and with the sucrose concentration of the $585 \mathrm{ml}$ gradient nearest the rotor core specified as $5 \%(\mathrm{w} / \mathrm{w})$. Because of the presence of overlay and sample between the rotor core and the start of the continuous gradient, the sucrose concentration at the sample zone-gradient interface was higher than $5 \%(w / w)$. The value of the mean buoyant density of cells used in the computation of the gradient profile was $1.13 \mathrm{~g} \mathrm{ml}^{-1}$ and was determined in gradients of colloidal silica (Ludox) as described by Poole (1977a); it was assumed that cells are of this density in sucrose solutions. Physical properties of sucrose solutions were taken from the data of Barber (1966).

Gradients were prepared from stock solutions of sucrose $(9 \cdot 1$ and $23.8 \%, w / w$, respectively), dissolved in medium lacking carbon source but with sodium citrate (Poole, 1977a), and loaded into the zonal rotor using a Gilson Mixograd automatic gradient former (with valve 45100) and a Gilson Minipuls 2 pump (Anachem, Luton LU2 7QE). The gradient former mixed the two sucrose solutions, which constituted the least and most dense extremes of the gradient, respectively, by continuously varying the ratio of the volumes of each component pumped. Computed gradient profiles were represented by paper templates that were photoelectrically scanned to control the contribution of flow from each sucrose solution to the effluent gradient. The rotor was loaded at $12.5 \mathrm{ml} \mathrm{min}^{-1}$ while rotating at $750 \mathrm{rev} . \mathrm{min}^{-1}$ at $4{ }^{\circ} \mathrm{C}$ in an MSE High Speed 18 centrifuge fitted with a Low Speed Zonal Control. After loading of the $585 \mathrm{ml}$ gradient, the rotor was filled to the edge with $25 \%(w / w)$ sucrose. During loading, sucrose solutions were maintained on ice; all subsequent operations were carried out as close to $0{ }^{\circ} \mathrm{C}$ as possible.

The culture was harvested using a continuous action rotor, fitted with a high efficiency insert, operating at

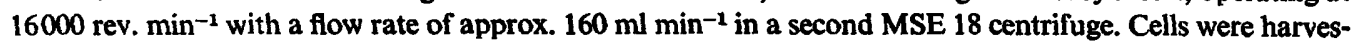
ted from the resulting concentrate by centrifugation at $7500 \mathrm{rev} \cdot \mathrm{min}^{-1}\left(8500 \mathrm{~g}\right.$ at $\left.r_{\max }\right)$ for $5 \mathrm{~min}$ in the $6 \times 250 \mathrm{ml}$ rotor of the same centrifuge and washed with the medium that lacked carbon source but contained sodium citrate, described above. They were finally resuspended in about $10 \mathrm{ml} 5 \%(\mathrm{w} / \mathrm{w})$ sucrose in the same citrate medium, aided by a few strokes of a loose-fitting hand-held homogenizer. The suspension was introduced to the rotor core and followed by an overlay of citrate-containing medium by pumping an equal volume of the $25 \%(\mathrm{w} / \mathrm{w})$ sucrose from the rotor edge. The combined volume of the sample and overlay was 
$30 \mathrm{ml}$. The rotor was accelerated to $6000 \mathrm{rev} \cdot \mathrm{min}^{-1}$ and the progress of cell sedimentation in the transparent rotor was followed using a Power Instruments Strobette model 964 Stroboscope (CP Instruments Co., Bishops Stortford, Herts.). When the leading edge of the band had sedimented to about $8.8 \mathrm{~cm}$ from the axis of rotation (typically after $10 \mathrm{~min}$ ), the rotor was decelerated to $750 \mathrm{rev} . \mathrm{min}^{-1}$ and unloaded by pumping $30 \%(w / w)$ sucrose solution to the outer wall of the rotor at about $25 \mathrm{ml} \mathrm{min}^{-1}$. Timing of all events during the fractionation, including acceleration and deceleration, allowed the total centrifugal field-time to be calculated and expressed by $\int_{0}^{t} \omega^{2} \mathrm{~d} t$, where $\omega$ is angular velocity (in rad s${ }^{-1}$ ) and $t$ is time (in s). Values for integrated field-time for this type of separation were $2 \times 10^{8}$ to $3 \times 10^{8} \mathrm{rad}^{2} \mathrm{~s}^{-1}$ for the period between sample loading and the end of fraction collection. Fractions $(17$ to $20 \mathrm{ml})$ were collected in $50 \mathrm{ml}$ centrifuge tubes on ice, their volumes were accurately measured, and $1 \mathrm{ml}$ portions were taken and fixed with $50 \mu 1$ formaldehyde solution. The remaining samples were diluted with $10 \mathrm{ml}$ of a buffer that contained $50 \mathrm{~mm}-\mathrm{Tris} / \mathrm{HCl}$ and $2.5 \mathrm{~mm}-\mathrm{MgCl}_{2}$ (pH 8) and centrifuged for $15 \mathrm{~min}$ at $15000 \mathrm{rev} \cdot \mathrm{min}^{-1}\left(26000 \mathrm{~g}\right.$ at $r_{\mathrm{max}}$ ). The cell pellets were resuspended in the same buffer and centrifuged for $10 \mathrm{~min}$ at $15000 \mathrm{rev}$. $\mathrm{min}^{-1}$. The cell pellets were resuspended in $5 \mathrm{ml}$ of the same buffer, $200 \mu 1$ samples were removed for cell number determinations and the remainder was used to prepare extracts of the bacteria. The entire separation procedure, from completion of harvesting to collection of fractions, lasted about $18 \mathrm{~min}$.

Prepuration of synchronous cultures. The method used was a scaled-up version of the size selection method of Mitchison \& Vincent (1965) using a zonal rotor (Poole et al., 1973). The culture was harvested by centrifugation at $7500 \mathrm{rev} . \mathrm{min}^{-1}\left(8500 \mathrm{~g}\right.$ at $\left.r_{\max }\right)$ for $5 \mathrm{~min}$ in the $6 \times 250 \mathrm{ml}$ rotor of an MSE18 centrifuge at about $37^{\circ} \mathrm{C}$. The basic procedure was the same as that described for fractionation into size classes, except that the computed 9.5 to $25 \%(\mathrm{w} / \mathrm{w})$ sucrose gradient was designed to be used at $30^{\circ} \mathrm{C}$. The temperature was maintained between 30 and $37^{\circ} \mathrm{C}$ by using a fan heater. All sucrose solutions were made in the complete growth medium (Poole et al., 1979) and the gradient was loaded at about $10 \mathrm{ml} \mathrm{min}^{-1}$. The rotor was accelerated to $5000 \mathrm{rev} \cdot \mathrm{min}^{-1}$. After deceleration $\left({ }_{0} \int^{t} \omega^{2} \mathrm{~d} t=1 \times 10^{8}\right.$ to $\left.2 \times 10^{8} \mathrm{rad}^{2} \mathrm{~s}^{-1}\right)$, the rotor effluent was monitored until cells appeared. The first 30 to $40 \mathrm{ml}$ of eluate containing cells was collected and inoculated into a growth vessel containing 1.01 of the supernatant collected during harvesting of the original culture (spent medium). The medium was vigorously aerated and incubated at $37^{\circ} \mathrm{C}$. At 6 to 10 min intervals, $40 \mathrm{ml}$ samples were removed from the culture and filtered through a Nuclepore nitrocellulose membrane filter $(50 \mathrm{~mm}$ diam.; $0.22 \mu \mathrm{m}$ pore size; Sterilin, Teddington, Middlesex). Filtered cells were resuspended in $5 \mathrm{ml}$ of the ice-cold $\left(4{ }^{\circ} \mathrm{C}\right) \mathrm{Tris} / \mathrm{Mg}^{2+}$ buffer described above and $200 \mu \mathrm{l}$ portions were retained for cell size and number determinations. The remainder was used to prepare extracts of bacteria.

Preparation of cell-free extracts. The method described by Gibson et al. (1980) was used except that the sonicator probe had an end diameter of $9.5 \mathrm{~mm}$. The suspension was centrifuged at $4{ }^{\circ} \mathrm{C}$ and $15000 \mathrm{rev}$. $\min ^{-1}\left(26000 \mathrm{~g}\right.$ at $\left.r_{\text {max }}\right)$ for $15 \mathrm{~min}$ to yield a turbid supernatant in which ATPase activity was determined.

Assay of ATPase activity (EC 3.6.1.3). The assay was based on monitoring the release of $P_{1}$ and closely followed method III of Tsuchiya \& Rosen (1975). The assay mixture contained (in $410 \mu \mathrm{l}$ ) up to $100 \mu \mathrm{g}$ extract protein, $1.5 \mu \mathrm{mol}$ ATP, $20.5 \mu \mathrm{mol}$ Tris/ $\mathrm{HCl}, 1.025 \mu \mathrm{mol} \mathrm{MgCl}_{2}, 20.5 \mu \mathrm{mol} \mathrm{KCl}, 0.1 \mathrm{mg}$ bovine serum albumin, approx. 1 unit of pyruvate kinase and $0.52 \mu \mathrm{mol}$ phosphoenolpyruvate. The mixture was incubated at $37^{\circ} \mathrm{C}$ and the reaction was started by adding the extract. After $10 \mathrm{~min}$, the reaction was stopped by adding $640 \mu \mathrm{l}$ of cold $\left(4^{\circ} \mathrm{C}\right) 0.5 \mathrm{M}$-trichloroacetic acid. The assay tubes were stored on ice and $3.0 \mathrm{ml}$ of a reagent that contained $1.7 \%(\mathrm{w} / \mathrm{v})$ ascorbic acid, $0.82 \%(\mathrm{w} / \mathrm{v})$ ammonium molybdate and $0.82 \mathrm{M}-\mathrm{H}_{2} \mathrm{SO}_{4}$ was added. After incubation at $37^{\circ} \mathrm{C}$ for $30 \mathrm{~min}$, the tubes were centrifuged at $4{ }^{\circ} \mathrm{C}$ at about half-maximal speed for $5 \mathrm{~min}$ in a Microangle bench centrifuge (Baird \& Tatlock, Chadwell Heath, Essex). The intensity of the blue colour in the supernatants was measured at $660 \mathrm{~nm}$. $\mathrm{KH}_{2} \mathrm{PO}_{4}$ (AnalaR grade) was used as a standard. For assay of fractions containing Ruthenium Red, the inhibitor was included in the standards at the appropriate concentration. Under the conditions described, $P_{i}$ release was linear with up to about $160 \mu \mathrm{g}$ cell extract protein, over a period of about $15 \mathrm{~min}$. Appropriate controls allowed for non-enzymic ATP hydrolysis and for contamination of the assay components with $\mathbf{P}_{\mathbf{i}}$ or ATP.

Ruthenium Red was dissolved in water to give $14.3 \mu \mathrm{g} \mathrm{ml}^{-1}$ and added to the reaction mixture, before the extract, to give the final concentrations indicated in Results.

Cell numbers and volumes. These were determined using a Coulter counter model $\mathrm{Z}_{\mathrm{B} 1}$ and Channelyzer $\mathrm{Cl} 1000$ as described by Poole (1977a). The counter and associated equipment was housed and used in a screened wire cage to minimize electrical interference.

Assessment of synchrony. The synchrony index, $F$, described by Blumenthal \& Zahler (1962) was used. The value used for the mean generation time, $g$, was taken to be the doubling time for total cell volume. Subscripts to $F$ refer to the cell division measured.

Protein determination. Protein in cell-free extracts was determined by Lowry's method, using dry bovine plasma albumin as standard. The total protein content of suspensions of intact cells was determined in $0.5 \mathrm{M}$ $\mathrm{NaOH}$ extracts as described by Herbert et al. (1971) with the same standard. 
Chemicals. Commercial Ruthenium Red also contains Ruthenium Brown and Ruthenium Violet; the preparation used here was from Sigma and contained a minimum of $20 \%(w / w)$ Ruthenium Red. ATP (Sigma grade, disodium salt), phosphoenolpyruvate (trimonocyclohexylammoniumsalt)and pyruvate kinase (from rabbit muscle, type II) were also from Sigma.

\section{RESULTS}

\section{Growth and ATPase activities of synchronous cultures}

When cells harvested from an exponentially growing culture were centrifuged through an equivolumetric sucrose gradient in a zonal rotor, the number distribution and volumes of cells in successive eluted fractions were as shown in Fig. 1(a). The band of cells was well separated from the starting zone, which corresponded to the first $30 \mathrm{ml}$ eluted. Cell numbers rose sharply in the first six cell-containing fractions and declined slowly, giving a skewed distribution. Modal and mean cell volumes increased almost linearly with respect to gradient volume and increased by more than 2 -fold across the gradient (mean volume, $2 \cdot 2$-fold; modal volume, $2 \cdot 75$-fold). The closeness of the values for mean and mode in each fraction and the similar patterns of increase for both across the gradient demonstrate that the cell volumes in each fraction were almost normally distributed about the mode and that the skewness was relatively constant in successive fractions. To demonstrate that the fractionation shown in Fig. 1 (a) separates cells into age classes, as well as size classes, fractions were removed from the rotor and immediately inoculated into spent growth medium. Figure $1(b)$ shows the subsequent growth of cells taken from near the outer edge of the cell band. After a lag of about $10 \mathrm{~min}$, there was the onset of a synchronous division that was reflected in the stepwise increase in numbers and the rapid fall in modal cell volume; two subsequent synchronous divisions were seen. The periodicity of divisions, measured either between successive mid-points in rises of cell numbers, or between successive maxima in modal volumes, was 80 to $90 \mathrm{~min}$. Total cell volume [a measure of biomass (Williams, 1971)] in the culture increased smoothly; the line shown (fitted by eye) assumes an exponential increase and has a doubling time of $84 \mathrm{~min}$, similar to the mean generation time (about $90 \mathrm{~min}$ ) in exponentially growing cultures.

In Fig. $1(c)$, cells nearer the middle of the gradient were taken. Increase in modal volume occurred for about 40 min before decreasing and there was a somewhat longer initial plateau in cell numbers compared with the growth pattern seen in Fig. 1(b). The doubling time for total cell volume was $90 \mathrm{~min}$. When the smallest cells in the rotor were selected (Fig. $1 d$ ), the delay between inoculation and cell division was longer than that seen with the cells used in Fig. $1(b)$ or $(c)$, although the overall growth rate determined from total cell volume was similar $(88 \mathrm{~min})$.

In a number of experiments in which synchronous growth initiated by selection of the smallest cells was monitored over periods of about $3 \mathrm{~h}$, severe decay of synchrony was observed by the time of the second division. Similar reports of the rapid decay of synchrony under conditions of 'slow growth' (doubling times of 80 to $90 \mathrm{~min}$ ) with succinate as carbon source have recently been made by Plank \& Harvey (1979) and taken to suggest a motherdaughter generation time correlation coefficient of close to zero. For this reason, most experiments involving measurements of ATPase activity were restricted to frequent sampling of the first cell cycle, although similar patterns of change in enzyme activity were observed in the second partially synchronized cycle (see later, Fig. 8).

Figure 2 shows, on an expanded time scale, the first 100 min of growth of a synchronous culture prepared by selection of the smallest cells from a sucrose gradient. Cell numbers (Fig. $2 a$ ) began to increase after about $40 \mathrm{~min}$, followed by a rapid decrease in modal cell volume at 65 to $70 \mathrm{~min}$, and the mid-point of the increase in cell numbers with respect to the initial plateau level occurred at $80 \mathrm{~min}$. Total cell volume increased continuously (Fig. $2 a$ ); the line shown is that of best fit and has a doubling time of $84 \mathrm{~min}$. The 

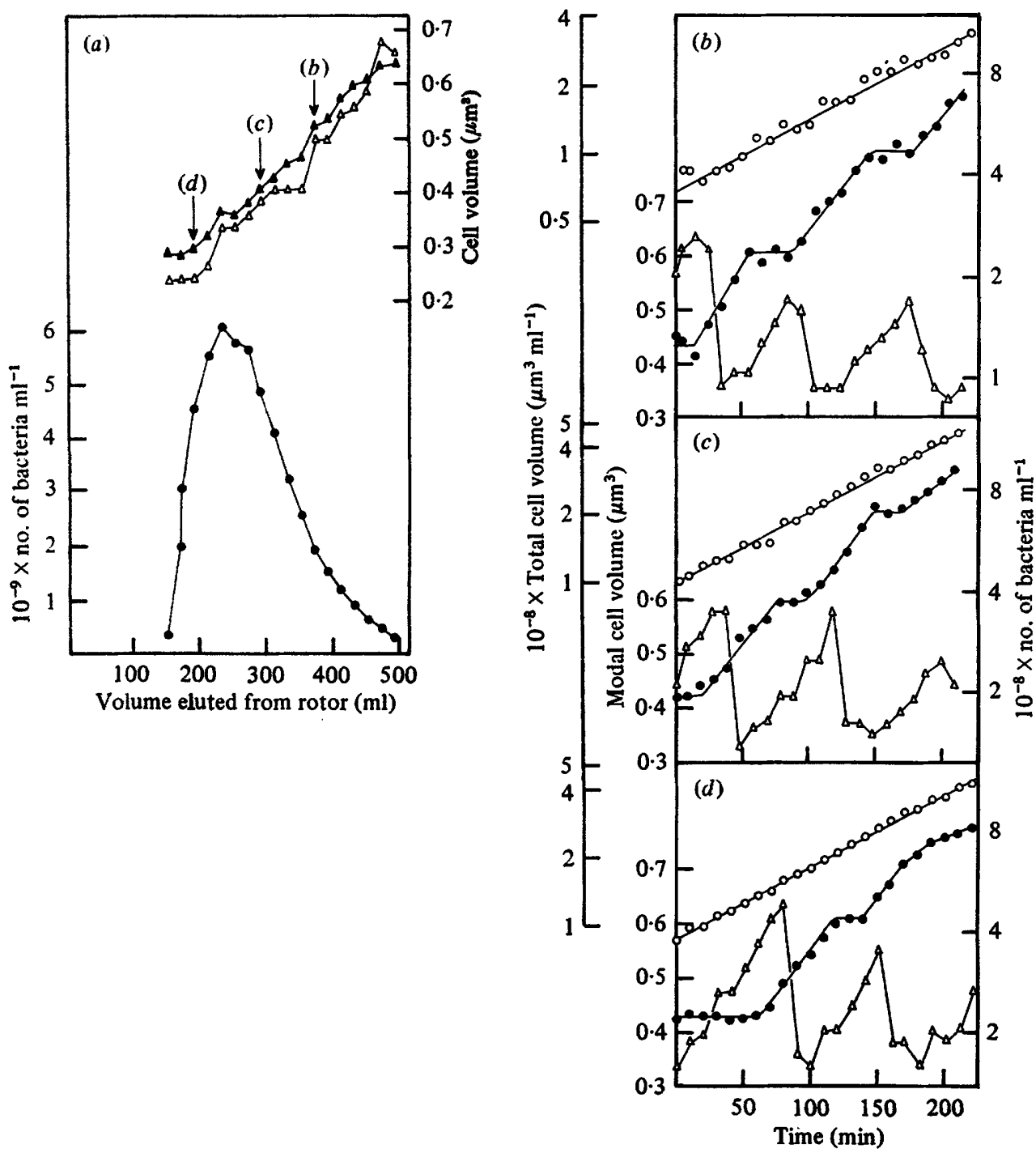

Fig. 1. Synchronous cultures of $E$. coli prepared by large-scale zonal fractionation of a population into size classes. The rotor was loaded with thecells harvested from 1.21 of an exponentially growing culture. The integrated field-time was $2.19 \times 10^{8} \mathrm{rad}^{2} \mathrm{~s}^{-1}$. In $(a)$, the distribution of cells $(O)$ in the gradient and the mean $(\Delta)$ and modal $(\Delta)$ volumes of cells in successive fractions are shown. In $(b),(c)$ and $(d)$ are shown synchronous cultures prepared by taking $3 \mathrm{ml}, 2 \mathrm{ml}$ and $3 \mathrm{ml}$ portions, respectively, of the eluted gradient at the points arrowed in $(a)$ and inoculating each into $50 \mathrm{ml}$ spent growth medium; measurements were made of cell numbers $(O)$, total cell volume $(O)$ and modal cell volume $(\Delta)$. The synchrony indices are as follows: $(b) F_{1}=0.73, F_{2}=0.50 ;(c) F_{1}=$ $0 \cdot 36, F_{2}=0.39 ;(d) F_{1}=0.41$.

correlation coefficient, $r$, was 0.993 . Similarly, the doubling time for total protein was $98 \mathrm{~min}$, although the correlation coefficient was slightly poorer $(0.977)$, probably due in part to quantitative errors in harvesting and resuspending the cells. Figure $2(b)$ shows the percentage of the total protein released by sonication for each cell suspension; the ATPase activities (expressed on a per cell basis) have been corrected to $100 \%$ protein release. Three continuous lines are drawn through the data points for ATPase activity in the absence of inhibitor. The middle line shows the theoretical ATPase activity (on a per cell 

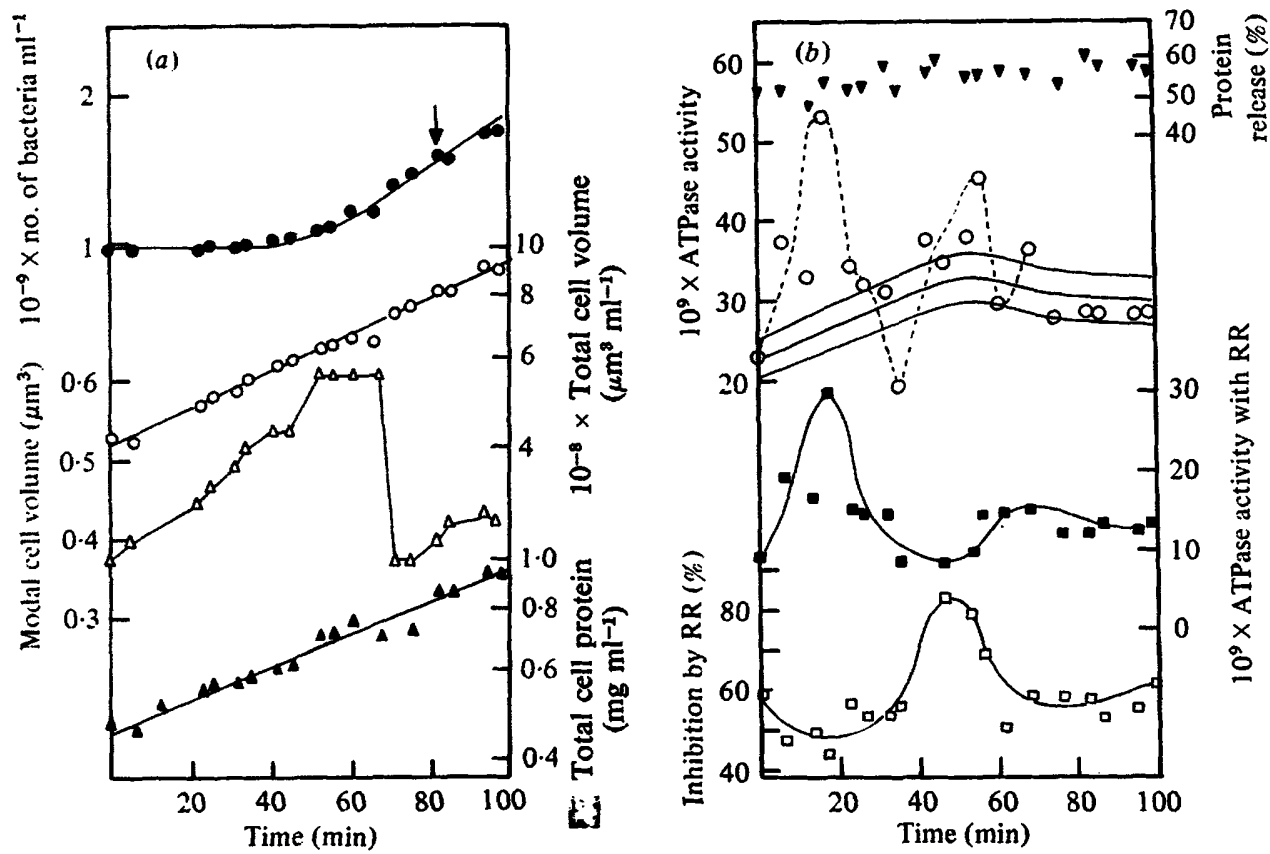

Fig. 2. Changes in cell numbers, volumes, protein and ATPase activities in a synchronous culture of $E$. coli. The sucrose gradient was loaded with the cells harvested from 41 of an exponentially growing culture. The integrated force-timewas $1.7 \times 10^{8} \mathrm{rad}^{2} \mathrm{~s}^{-1}$. Approx. $11 \%$ of the loaded cells were taken from the eluted gradient and used to inoculate spent growth medium. In (a), the change in cell numbers $(\Theta)$, total cell volume $(O)$, modal cell volume $(\Delta)$ and total protein $(\Delta)$ are shown. In $(b)$, the changes in the percentage of total protein released by sonication $(\nabla)$, ATPase activity in the absence $(O)$ and presence $(\mathbb{D})$ of $75 \mu \mathrm{M}$-Ruthenium Red (RR) and the percentage inhibition of ATPase activity by Ruthenium Red $(\square)$ are shown. All ATPase activities are expressed as nmol ATP hydrolysed $\mathrm{min}^{-1}$ cell-1. The lines drawn through the experimental points for ATPase activity are explained in the text.

basis), calculated assuming that activity increases exponentially through the cycle with a doubling time equal to that of the total cell volume (the null hypothesis). The reproducibility of the entire procedure for preparation of cell-free extracts, assay of enzyme activity and determination of cell numbers was determined in a separate experiment (shown later, Fig. 7) and the standard deviation and coefficient of variation of the results were calculated. The coefficient of variation (= standard deviation/mean) was 0.047 . The upper and lower lines through the data points indicate the extent of two standard deviations above and below the theoretical curve. The probability of experimental points lying outside this range is 1 in 20, assuming that the null hypothesis is valid. The experimental data are not consistent with the hypothesis that enzyme activity increases continuously through the cell cycle. Based on results obtained in three similar experiments and after culture fractionation (see, later, Fig. 8), it is proposed that a satisfactory fit to the data is given by an oscillating ATPase activity shown by the dashed line with two maxima between inoculation and the end of the first cell cycle. The inclusion of $75 \mu \mathrm{M}$-Ruthenium Red exerted a differential effect on the oscillations in activity (Fig. $2 b$ ). The first peak of activity at about 20 min was inhibited by only 45 to $50 \%$ whilst maximum inhibition ( $83 \%$ ) occurred closer to the time of the second peak at 45 to $50 \mathrm{~min}$. Impurities in the inhibitor preparations, Ruthenium Brown and Ruthenium Violet, also inhibit ATPase activity, though somewhat less effectively than Ruthenium Red (Scherr \& Günther, 1978). Inhibitor concentrations given assume purity of the Ruthenium Red. 


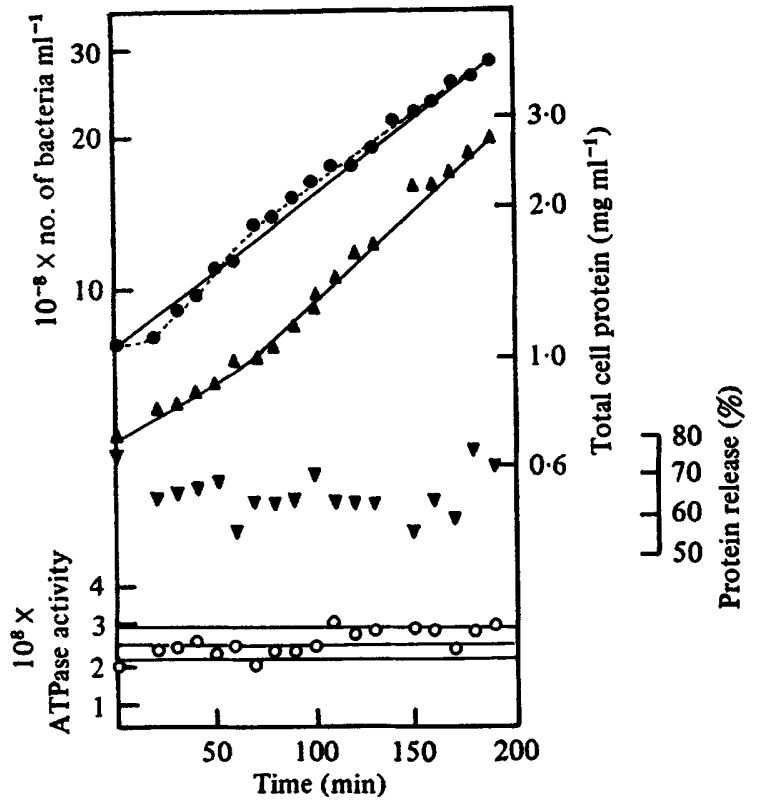

Fig. 3. Changes in cell numbers, protein and ATPase activity in a control culture. The sucrose gradient was loaded with the cells harvested from 2.51 of an exponentially growing culture. The zonal rotor was operated until the bulk of the cells had sedimented to about $8 \mathrm{~cm}$ from the axis of rotation (integrated force-time $3.36 \times 10^{7} \mathrm{rad}^{2} \mathrm{~s}^{-1}$ ), i.e. to the sucrose concentration to which cells normally selected for initiating synchrony were exposed. That region of the gradient containing cells was eluted, mixed and a portion that contained about $18 \%$ of the total number of cells loaded was inoculated into 11 of spent growth medium. The changes in cell number $(O)$, total cell protein $(\Delta)$, the percentage of protein released by sonication $(\boldsymbol{\nabla})$ and ATPase activity $(O)$ are shown. ATPase activities are expressed as nmol ATP hydrolysed min $^{-1}$ cell ${ }^{-1}$. The lines drawn through the experimental points for ATPase activity are explained in the text.

\section{Growth and ATPase activities of control asynchronous cultures}

To determine the effect, if any, of the gradient selection procedure on ATPase activity during subsequent growth, control asynchronous cultures were prepared by mixing the fractionated cells together and inoculating a small portion into spent growth medium. A representative experiment, of three conducted, is shown in Fig. 3. The increase in cell numbers can be well-fitted by a line indicating exponential growth with a doubling time of $96 \mathrm{~min}$, although there is some evidence for small deviations from this pattern (correlation coefficient, $r=0.994$ ). Total protein also increased continuously, perhaps with a rate change at about $75 \mathrm{~min}$. Despite large fluctuations in the proportion of total cell protein recovered after sonication and differential centrifugation, the corrected values for ATPase activity per cell were relatively constant. The mean value $\left(26.65 \times 10^{-8} \mathrm{nmol}\right.$ ATP hydrolysed $\min ^{-1}$ cell $^{-1}$ ) is represented by the middle line through the data points for ATPase activity. All values lie very close to, or within, two standard deviations of the mean (indicated by the upper and lower horizontal lines). The results illustrate that the fluctuations in enzyme activity in the synchronous culture are not the result of the synchronization procedure.

\section{Analysis of the cell cycle by zonal fractionation of a population into size classes}

In the experiment shown in Fig. 4, cells from an exponentially growing culture were subjected to rate zonal centrifugation at $4{ }^{\circ} \mathrm{C}$. The distribution of cell numbers and volumes (Fig. $4 a$ ) was similar to that obtained at about $30^{\circ} \mathrm{C}$ (Fig. $1 a$ ). The increases in cell volumes achieved across the gradient were $2 \cdot 6$-fold for mean volume and $3 \cdot 2$-fold for modal volume. 

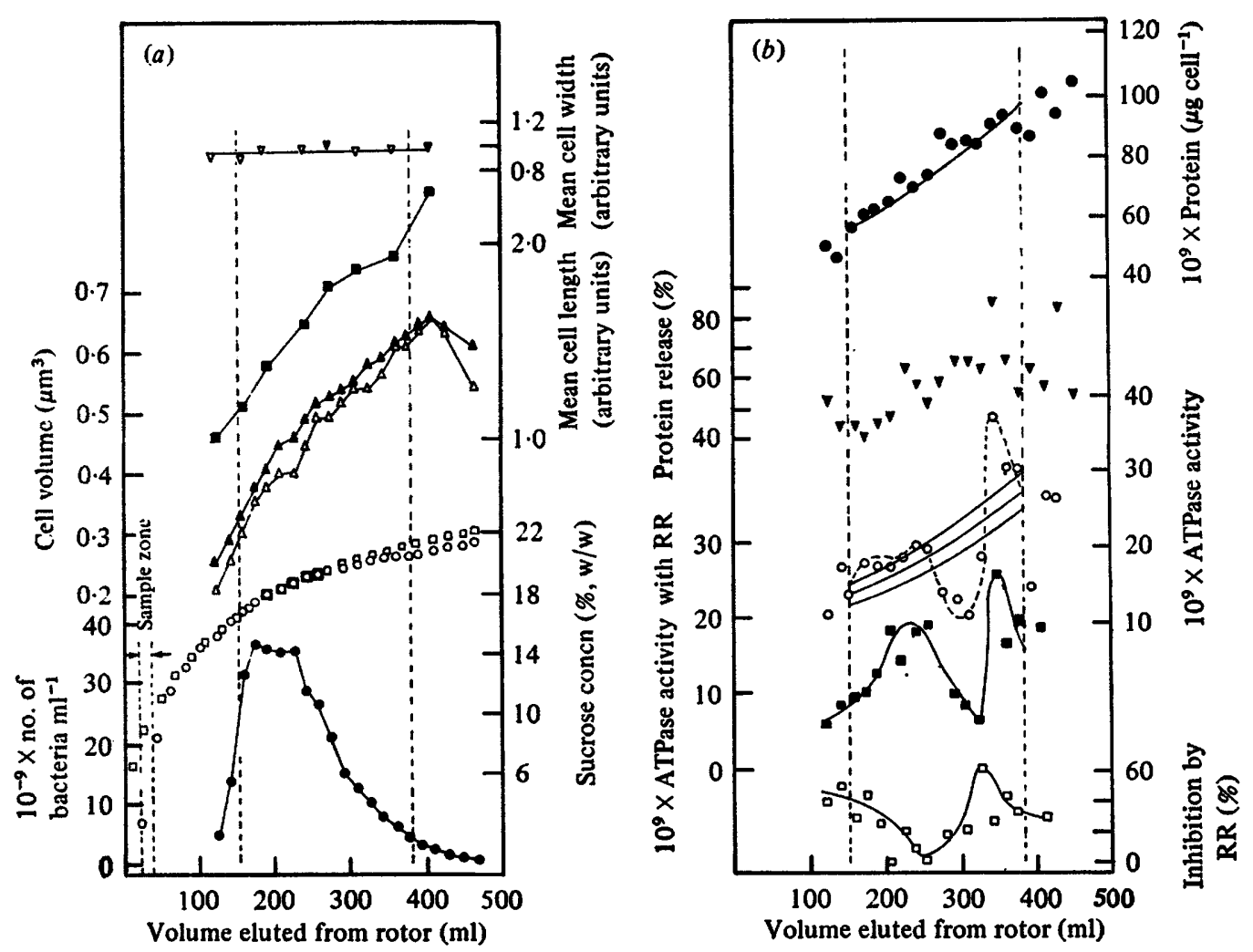

Fig. 4. Analysis of the cell cycle of $E$. coli by zonal fractionation into size classes of cells from an exponentially growing culture. The rotor was loaded with the cells harvested from 31 of an exponentially growing culture. The integrated force-time was $3.5 \times 10^{8} \mathrm{rad}^{2} \mathrm{~s}^{-1}$. In $(a)$, cell numbers $(\odot)$, sucrose concentration $(O)$, the theoretical profile of an equivolumetric gradient ( $\square$ ), modal $(\Delta)$ and mean $(\Delta)$ cell volumes, and, measured from electron micrographs, cell length $(\boldsymbol{D})$ and width $(\nabla)$ are shown. In $(b)$, total protein per cell $(\Theta)$, the percentage of protein released by sonication $(\nabla)$, ATPase activity in the absence $(O)$ and presence $(\nabla)$ of $75 \mu \mathrm{M}-$ Ruthenium Red (RR) and the percentage inhibition of ATPase activity by Ruthenium Red $(\square)$ are shown. All ATPase activities are expressed as nmol ATP hydrolysed $\min ^{-1}$ cell-1. Also shown in (a) is the position of the initial sample zone. The vertical dashed lines at $146 \mathrm{ml}$ and $382 \mathrm{ml}$ define a doubling in mean cell volume $(\Lambda)$ and indicate the average cell volume at birth and division, respectively, assuming that increase in cell volume is linear through the cell cycle. The lines drawn through the experimental points for ATPase activity are explained in the text.

Figure 5 shows volume distributions in selected fractions and compares them with that of the exponentially growing culture. For most of the rotor volume, the gradient was shallow, closely following the theoretical profile of an equivolumetric gradient, and allowed maximal resolution of the population into size classes (Fig. $4 a$ ). The dimensions of cells measured from electron micrographs show that cell length increased $2 \cdot 2$-fold across the rotor, whilst cell width remained essentially constant.

Examination of volume distributions of cells from exponentially growing cultures (e.g. Figs $5 a$ and 6 ) reveals a large dispersion of cell volumes over a 3-or 4-fold range. Thus, zonal fractionation on the basis of cell size should resolve a similar range of volumes, and this is achieved in the experiment shown in Fig. 4(a). However, since volumes of cells of a given age are themselves normally distributed, such a wide range of resolved sizes includes those cells that are smaller than the average cell at birth (a neonatal cell) and larger than the average cell about to divide (an incipient cell). A suitable approximation of the mean volumes 


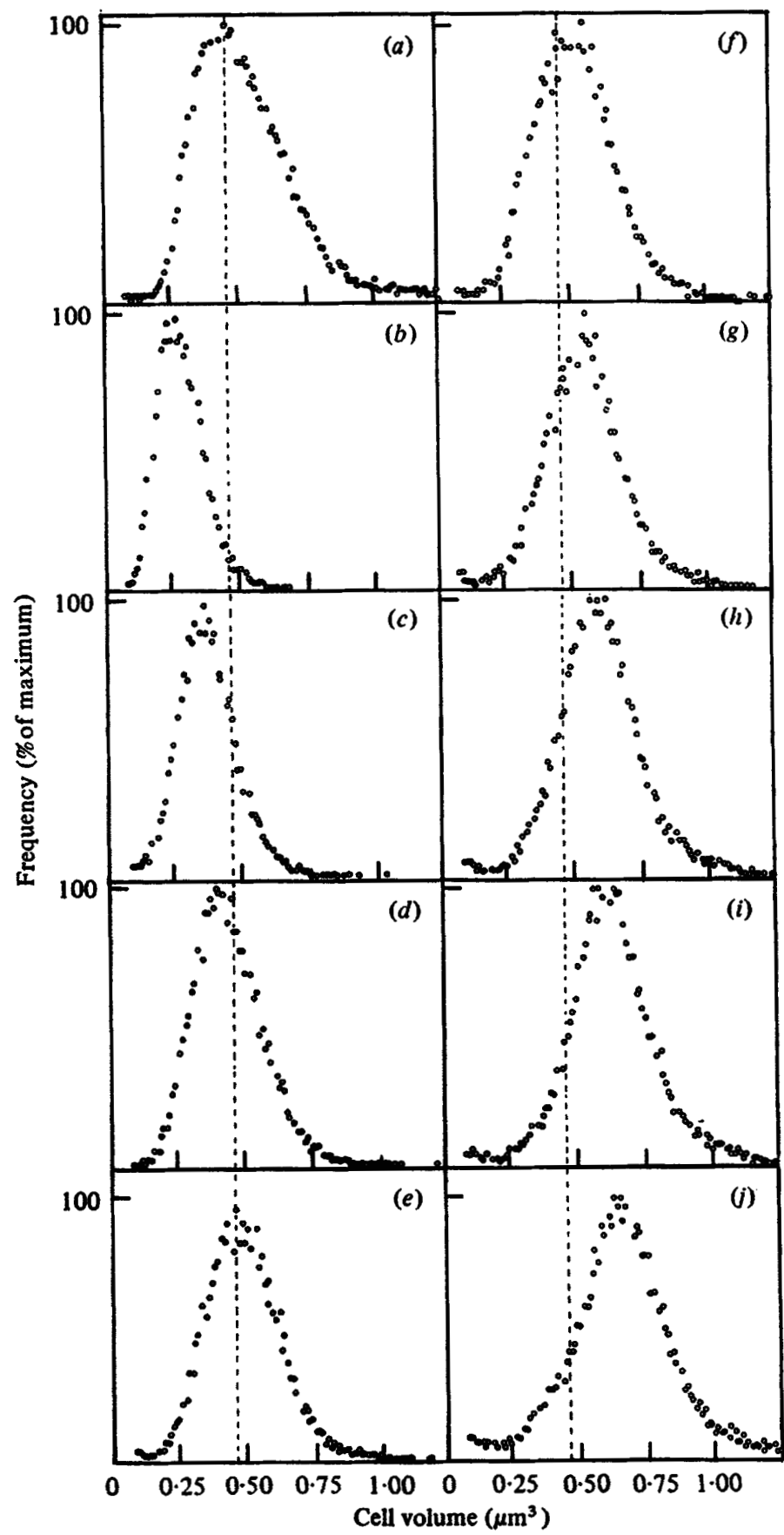

Fig. 5. Frequency distributions of cell volumes for an exponentially growing cultureand populations obtained by zonal fractionation of such a culture into size classes. In each of $(a)$ to $(j)$, the symbols indicate the observed frequency (as a percentage of the maximum) of cell numbers in each of 100 size channels, determined using a Coulter counter and Channelyzer $\mathbf{C 1 0 0 0}$. The distributions shown are for an exponentially growing culture (a) and for the cells eluted in the experiment in Fig. 4 from 124 to $141 \mathrm{ml}(b), 158$ to $175 \mathrm{ml}(c), 190$ to $207 \mathrm{ml}(d), 225$ to $242 \mathrm{ml}(e), 257$ to $275 \mathrm{ml}$ (f), 293 to $310 \mathrm{ml}(g), 328$ to $345 \mathrm{ml}(h), 360$ to $377 \mathrm{ml}(i)$ and 394 to $412 \mathrm{ml}(j)$. Distributions (c) to (i) inclusive span a doubling in mean cell volume and are considered to represent the extent of the cell cycle. The vertical dashed lines represent the modal volume of the unfractionated population shown in $(a)$, which has a value of $0.445 \mu \mathrm{m}^{3}$. 


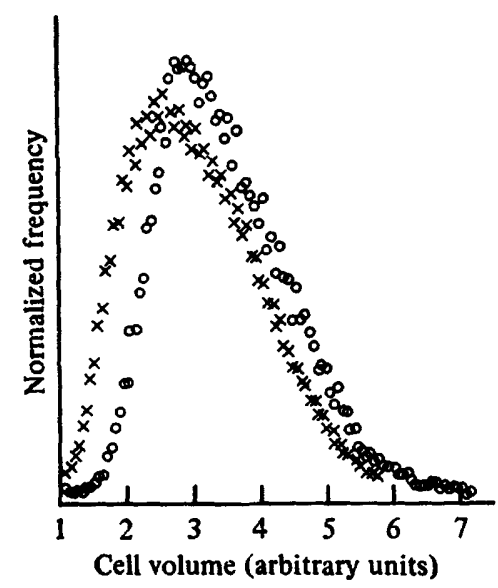

Fig. 6. Comparison of the volume distribution of a cell population before and after centrifugation through a sucrose gradient. The data points $(O)$ show, for a population of exponentially growing cells, frequencies (in arbitrary units) of cell numbers observed in each of 100 size classes, determined using a Coulter counter and Channelyzer. The volume distributions of cells in fractions from a zonal separation experiment (shown in Fig. 4) were summed and normalized by computer to yield the distribution shown by the second set of points $(x)$.

of cells at birth $\left(\bar{V}_{b}\right)$ and at the moment of division $\left(\bar{V}_{\mathrm{d}}\right)$ is given by $\bar{V}_{\mathrm{b}}=\bar{V} \ln 2=\bar{V}_{\mathrm{d}} / 2$, where $\bar{V}$ is the mean volume of cells in an exponential culture (Kubitschek et al., 1967). The relationship assumes that cell volume increases linearly with time from birth to fission (Kubitschek, 1968) and that there is no variability in cell volume at birth or at fission. Although only an approximation, it enables intradivision measurements to be made as a function of cell volume. The mean volume of cells recovered in the gradient was calculated (allowing for the number of cells in each fraction) and used to calculate the mean cell volumes at birth and division, indicated by the two dashed vertical lines shown extending from top to bottom in Fig. 4(a) and (b). Cells recovered in the gradient eluted from the rotor are smaller than those initially loaded, perhaps due to plasmolysis (Alemohammad \& Knowles, 1974), as shown in Fig. 6. However, the shape of the volume distribution is essentially unchanged, indicating that all cells in the population are affected similarly. In the typical experiment shown in Fig. 4, the mean volume of cells in the collected gradient fractions was $0.45 \mu \mathrm{m}^{3}$, compared with $0.53 \mu \mathrm{m}^{3}$ for the exponentially growing culture.

Total protein, expressed per cell, increased across the rotor radius (Fig. $4 b$ ). In that portion of the gradient that is assumed to represent the cell cycle, the data are well-fitted by either a linear (correlation coefficient, $r=0.93$ ) or an exponential (correlation coefficient, $r=0.94)$ increase and the latter is shown in Fig. 4(b). Protein per cell increased 1.8-fold over the idealized cell cycle. The proportion of protein released by sonication varied considerably. We have observed such variation in synchronous cultures, asynchronous control cultures and in fractions resolved by zonal centrifugation, but no regular pattern in the susceptibility of cells to breakage with respect to the cell cycle (see Clark, 1968) has been noted. The values for ATPase activity have been fitted by eye with a dashed line that exhibits two maxima in the cell cycle. The three continuous lines drawn through the data have the same meaning as those in Figs. $2(b)$ and 3. In this case, the cell cycle is assumed to be linearly represented between the two vertical dashed lines and the null hypothesis line is again the curve representing an exponential increase in enzyme activity that doubles during the cell cycle. Only two fractions exhibited activities that fell within two standard deviations of the theoretical curve. The sensitivity of the oscillating activity to Ruthenium Red again 


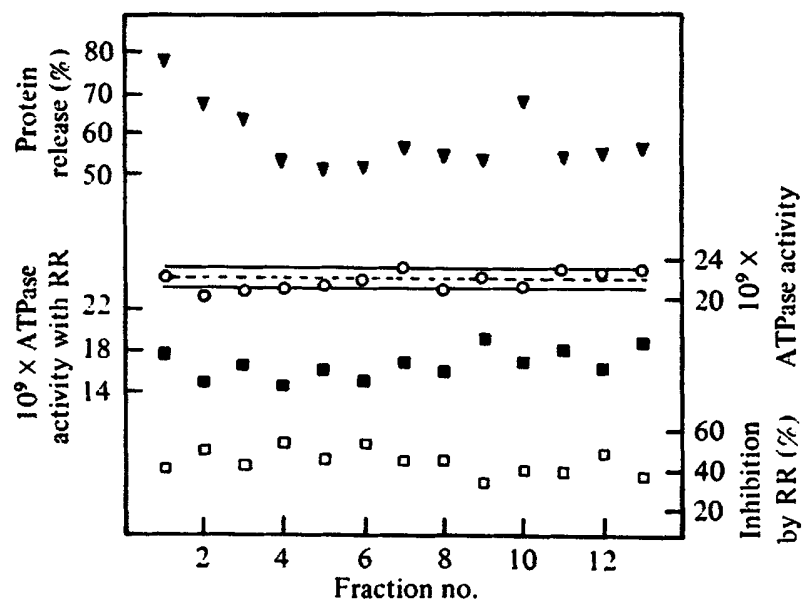

Fig. 7. Reproducibility of the determinations of ATPase activity and its sensitivity to Ruthenium Red in identical cell fractions from a sucrose gradient. The rotor was loaded with the cells from 1.51 of an exponentially growing culture. The integrated force-time was $2.56 \times 10^{8} \mathrm{rad}^{2} \mathrm{~s}^{-1}$. The rotor was unloaded, and the eluted gradient containing the cells was mixed and divided into 13 aliquots. For each aliquot the percentage of protein released by sonication $(\nabla)$, the ATPase activity in the

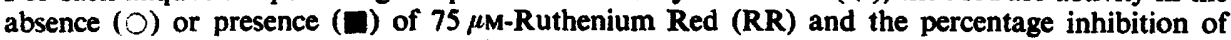
ATPase activity by Ruthenium Red ( $\square$ ) was measured. All ATPase activities are expressed as nmol ATP hydrolysed $\min ^{-1}$ cell $^{-1}$. The dashed line represents the mean ATPase activity in the absence of inhibitor and the continuous lines the limits of one standard deviation above and below the mean.

fluctuated during the cycle, maximum sensitivity occurring close to the time of minimal activity.

\section{Reproducibility of the ATPase assay procedure}

A control experiment was done in which an exponentially growing culture was fractionated by zonal centrifugation into size classes. The collected fractions were mixed, divided into 13 samples and assayed for ATPase activity in the absence and presence of Ruthenium Red. Despite fluctuations in the amount of released protein (Fig. 7), ATPase activity in the absence of inhibitor showed little variation and the mean value per cell (indicated by the dashed line in Fig. 7) was very close to that observed in synchronous and control asynchronous cultures. Similarly, fluctuations in the sensitivity to Ruthenium Red were small and clearly distinct from the variation shown in Fig. $4(b)$.

\section{Comparison of results from synchronous cultures and culture fractionations}

Figure 8 shows ATPase activities (measured in the absence of Ruthenium Red) in three separate synchronous cultures $(a, b, c)$ and three zonal fractionations $(d, e, f)$. In Fig. 8 $(a, b, c)$, the length of the cell cycle was assumed to be equal to the observed doubling time for total cell volume. This is validated by the finding (Fig. 1) that total cell volume doubles in a time interval equal to the periodicity of cell division, the latter being measured from plots of either cell numbers or volumes. All measurements [with the exception of those indicated by symbols in Fig. 8(a)] are from the first (incomplete) cell cycle whose termination was taken to be the mid-point of the precipitous drop in modal cell volume. This represents the point at which the parasynchronous population consists of equal numbers of divided and non-divided cells and precedes the mid-point of increase in cell numbers (when the frequency of neonatal cells is twice that of incipient cells). In Fig. $8(d, e, f)$, the limits of the cell cycle have been calculated from the mean volume of cells in the gradient as described earlier. In all six cases, the experimental data are well fitted by a line that describes an oscil- 


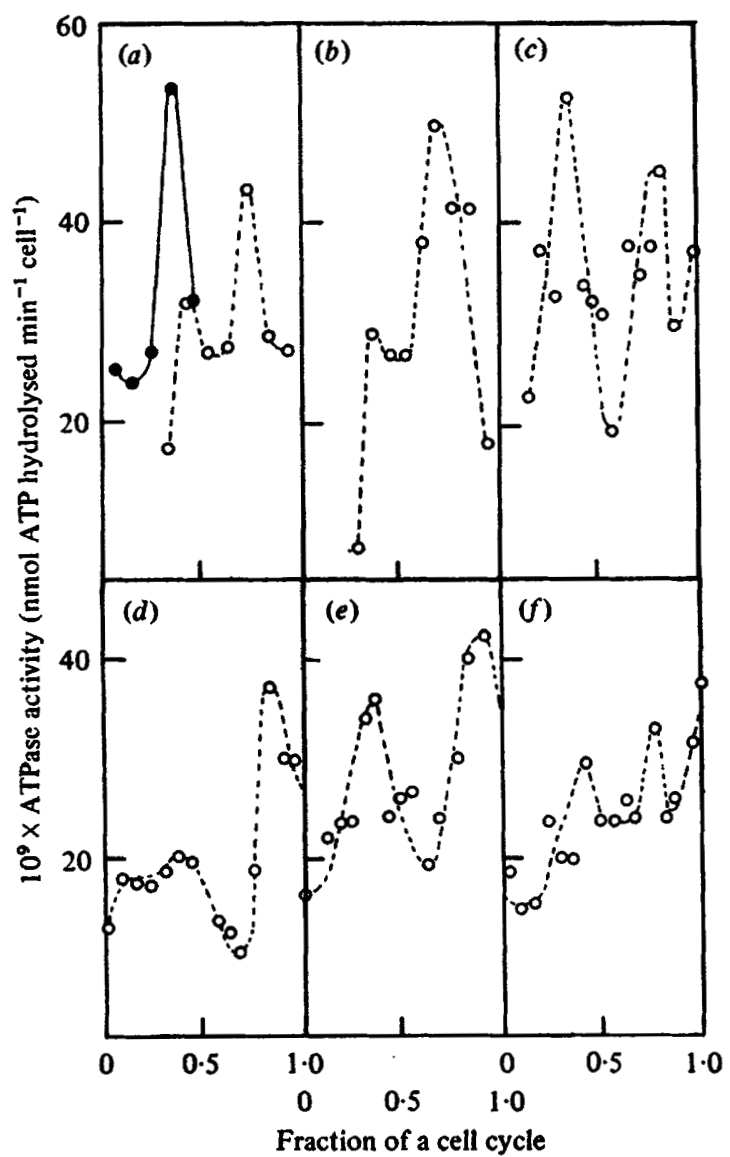

Fig. 8. Oscillations in ATPase activity observed in six individual experiments. In $(a),(b)$ and $(c)$, the results were obtained from the first cell cycle in synchronous cultures $(O)$ except for $(a)$, which also includes data from the second cycle (O). The end of the first cell cycle was taken to be the time of decrease in modal cell volume and the length of the cell cycle was taken to be the doubling time for total cell volume. In $(d),(e)$ and $(f)$, the results were obtained from zonal fractionations of populations into size (and age) classes. The limits of the cell cycle were calculated from the mean volume of cells in the gradient, assuming that increase in cell volume is linear through the cell cycle.

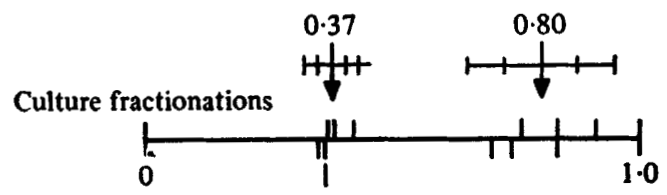

Synchronous cultures

Fig. 9. Cell cycle map summarizing the timings of maximum ATPase activity. The abscissa represents the cell cycle as a linear scale extending from 0 to 1.0 with cell division at its two limits. Each vertical bar represents the timing of maximum ATPase activity, taken from Fig. 8, for both synchronous culture experiments (below the abscissa) and zonal culture fractionation experiments (above the abscissa). The arrows indicate mean values (incorporating data from both types of experiments); the horizontal bars each show one and two standard deviations about the mean. 
latory pattern rising to two peaks in the cell cycle. In those experiments in which more frequent sampling was conducted, it would be possible to draw more complex patterns, but the precision of the experimental data is inadequate to support such curves. The measured ATPase activities showed good agreement whichever method of cell cycle analysis was employed. There was an approximate doubling in activity per cell in each case ( $a$ to $f$ ) but the high amplitude of the oscillations makes reliance on such measurements doubtful. In one experiment where ATPase activity was measured for longer than the first cycle, the timing of the maximum in the second cycle was almost coincident with the timing of the first peak in the first cycle.

The timings of the proposed maxima are summarized in Fig. 9, which is a linear representation of the cell cycle. Mean values for the timings of the maxima (incorporating data from both kinds of experiments ) are 0.37 and 0.80 of a cell cycle. The standard deviations are also shown and seen to be greater for the latter peak.

\section{DISCUSSION}

In this paper, we have sought to determine whether the activity of an enzyme increases discontinuously or continuously during the cell cycle of $E$. coli and to describe, as fully as possible, the pattern of increase.

Two methods of cell cycle analysis have been used, both based on separation (or selection) of discrete size (and thus age) classes from a heterogeneous population. Of the many ways of studying the events of the cell cycle available, the method of culture fractionation offers the particular advantage that very large quantities of cells can be separated. We sympathize with the view of Koch \& Blumberg (1976) who state: 'we feel that the method of choice is zonal gradient sizing of cells. When...fractionation is achieved rapidly in a way that does not depend upon the subsequent physiological behaviour of a perturbed cell population, then it seems to the authors that artifacts are minimal and experimental results amenable to clear and direct interpretation.' In addition, since it is believed (Koch \& Schaechter, 1962; Koch, 1978) that the determinants in the normal cell cycle that control key events are more directly related to cell size than to age, then an experimental method that generates size classes will be a priori more tightly coupled to the event under study than a method based upon age separation, such as membrane elution.

We have developed a density gradient method based on an established theoretical background to separate cells into size classes. In equivolumetric gradients, the volumetric distance that particles move through is proportional to their sedimentation coefficients and the width of particle zones remains independent of the distance migrated. In practice, such gradients are generally 'convex' with respect to rotor radius (Fig. 4) and offer further advantages as a consequence. Thus, the steepness of the gradient profile near the rotating axis allows a high loading capacity and, at greater radii, where the gradient profile is shallower, high resolution is attained (Lloyd \& Poole, 1979). This is illustrated by the wide range of cell sizes in successive fractions, the homogeneity of fractions, and the fact that the distribution of cell numbers in the gradient after separation on a size basis is of similar shape to the volume distribution of cells determined electronically for an unfractionated population. Comparison of the resolution attained with previous applications of the technique can be made by calculating the ratio of the largest cells separated to the smallest cells separated. Our values of 2.6 (mean volume) and 3.2 (modal volume) compare favourably with those presented in, or calculated from, previous reports. For $E$. coli these are: 1.9 to 2.0 (mean; Lutkenhaus et al., 1979); 1.74 (mode; Kubitschek et al., 1967); 1.67 (mode; Kung \& Glaser, 1977). Absorbance $\left(A_{585}\right)$ per cell, taken to be a measure of cell mass, increased linearly over an approximately 2 -fold range in a restricted portion of the sucrose gradient in the experiments of Beck \& Park (1976). 
We conclude that ATPase activity oscillates during the unperturbed cell cycle of succinategrown $E$. coli. This finding is based on the following considerations. (1) The fluctuations in enzyme activity observed following cell cycle analysis are well outside the estimated limits of error inherent in the determinations. (2) Control experiments show that the oscillations do not arise from perturbations of the behaviour of the synchronous culture. (3) Further control experiments show that culture fractionation does not adversely affect the subsequent reproducibility of the assay procedure. (4) There is good correlation between the timings of maximum activities with respect to the progress of the cell cycle when cell cycle analysis is carried out using two independent methods and when repeat experiments are conducted with either method alone.

ATPase activity has previously been shown to oscillate during the cell cycle of the yeast Schizosaccharomyces pombe (Edwards \& Lloyd, 1977; Lloyd \& Edwards, 1977) and of the bacterium Alcaligenes eutrophus (Edwards et al., 1978). The timings of maximum activities observed in synchronous cultures of the latter organism at 0.4 and 0.9 of the cycle are in very close agreement to the mean values described here for $E$. coli. In the case of $A$. eutrophus, maximum activities of ATPase have been shown to coincide with maximum rates of oxygen uptake (Edwards \& Jones, 1977) and minimum sensitivity of the ATPase activity to $N, N^{\prime}$-dicyclohexylcarbodiimide. Possible explanations for the mechanisms underlying oscillations in ATPase activity are given by Edwards et al. (1978) and are discussed with respect to inhibitor sensitivities below. Discontinuities in the rates of oxygen uptake during the cell cycle of $E$. coli have also been reported previously (Poole, 1977b). Respiration rates oscillate with a periodicity of half a cycle in synchronous cultures growing on glucose as major carbon source and prepared by continuous-flow age selection. These studies have already been extended to glycerol-grown cultures, in which $\mathrm{O}_{2}$ uptake increases in a stepwise fashion (Poole, 1977b), but any correlation between ATPase activity and respiration rates under the present experimental conditions must await the results of furtherstudies in progress in this laboratory.

Ruthenium Reds are polymeric compounds obtained by acidification of $\mathrm{Ru}\left(\mathrm{NH}_{3}\right)_{3} \mathrm{Cl}_{3}$. Originally used as stains for mucopolysaccharides, they have found extensive use as specific inhibitors of energy-dependent $\mathrm{Ca}^{2+}$ transport and binding processes in mitochondria (Moore, 1971). In addition, the $\mathrm{Ca}^{2+}$ - and $\mathrm{Mg}^{2+}$-stimulated ATPase of certain eukaryotic membrane systems such as microsomal preparations (Robinson, 1976) as well as of $E$. coli (Scherr \& Günther, 1978) are inhibited by Ruthenium Red. The latter authors showed that both membrane-bound ATPase and the enzyme released from membranes by washing with Tris and EDTA were sensitive to Ruthenium Red, which exhibited a 'mixed-type' inhibition. Using chemical treatments to remove specific subunits from the solubilized enzyme $\left(F_{1}\right)$, it was concluded that the Ruthenium Red inhibition was associated with the $\gamma$ or $\delta$ subunits. Thus, the action of Ruthenium Red appears to be similar to that of 4-chloro-7-nitrobenzofurazan, azide, the antibiotic Dio-9, quercetin and the zinc chelator, Zincon, all of which inhibit solubilized $\left(\mathrm{F}_{1}\right)$ ATPase activities of bacteria (for review, see Downie et al., 1979). If this is correct, then it is interesting that the fluctuations in sensitivity to Ruthenium Red in the cell cycle of $E$. coli do not bear the same relationship to maximum ATPase activities as is found for sensitivity to 4-chloro-7-nitrobenzofurazan in A. eutrophus (Edwards et al., 1978). In the latter system, maximum inhibition by 4-chloro-7-nitrobenzofurazan occurred concurrently with maximum ATPase activity, whilst Figs 2 and 4 of the present paper show that maximum sensitivity to Ruthenium Red and ATPase activity are out of phase. Whether these fluctuations arise from periodic changes in the availability of the inhibitor-reactive site (as suggested by Edwards et al., 1978) remains to be established.

We wish to thank Dr M. N. Hughes for valuable information on ruthenium compounds, Mr Ian Salmon for writing the computer program for designing sucrose gradients, Miss Virginia Bugeja for computing the data shown in Fig. 6, and Dr P. T. Saunders for advice 
on statistical treatment of the results. This work was generously supported by the Science Research Council through grant GR/A/2252.5 to R. K.P. and a CASE Research Studentship held by J.F.G.

\section{REFERENCES}

Alemohammad, M. M. \& Knowles, C. J. (1974). Osmotically induced volume and turbidity changes of Escherichia coll due to salts, sucrose and glycerol, with particular reference to the rapid permeation of glycerol into the cell. Journal of General Microbiology 82, 125-142.

BARBER, E. J. (1966). Calculation of density and viscosity of sucrose solutions as a function of concentration and temperature. In The Development of Zonal Centrifuges, pp. 219-239. Edited by N. G. Anderson. National Cancer Institute Monograph No. 21.

BECK, B. D. \& PARK, J. T. (1976). Activity of three murein hydrolases during the cell division cycle of Escherichia coli $\mathrm{K} 12$ as measured in toluenetreated cells. Journal of Bacteriology 126, 12501260.

Blumenthal, L. K. \& Zahler, S. A. (1962). Index for measurement of synchronization of cell populations. Science 135, 724.

Churchward, G. G. \& Holland, I. B. (1976). Envelope synthesis during the cell cycle in Escherichia coli B/r. Journal of Molecular Biology 105, 245-261.

Clark, D. J. (1968). The regulation of DNA replication and cell division in Escherichia coli $\mathrm{B} / r$. Cold Spring Harbor Symposia on Quantitative Biology 33, 823-838.

Creanor, J. \& Mirchison, J. M. (1979). Reduction of perturbations in leucine incorporation in synchronous cultures of Schizosaccharomyces pombe made by elutriation. Journal of General Microbiology 112, 385-388.

DONACHIE, W. D. (1979). The cell cycle of Escherichia coli. In The Developmental Biology of Prokaryotes, pp. 11-37. Edited by J. H. Parish. Oxford: Blackwell Scientific Publications.

Downif, J. A., Gibson, F. \& Cox, G. B. (1979). Membrane adenosine triphosphatases of prokaryotic cells. Annual Review of Biochemistry 48, 103131.

EDWARDS, C. \& Jones, C. W. (1977). Respiratory properties of synchronous cultures of Alcaligenes eutrophus H16 prepared by a continuous-flow size selection method. Journal of General Microbiology 99, 383-388.

Edwards, C., Spode, J. A. \& Jones, C. W. (1978). The properties of adenosine triphosphatase from exponential and synchronous cultures of Alcaligenes eutrophus H16. Biochemical Journal 172, 253260.

EDWARDS, S. W. \& LLOYD, D. (1977). Mitochondrial adenosine triphosphatase of the fission yeast, Schizosaccharomyces pombe $972 \mathrm{~h}^{-}$. Changes in activity and oligomycin-sensitivity during the cell cycle of catabolite-repressed and -de-repressed cells. Biochemical Journal 162, 39-46.

Gibson, J. F., Hadfield, S. G., Hughes, M. N. \&
Poole, R. K. (1980). Effects of trialkyllead compounds on growth, respiration and ion transport in Escherichia coli K12. Journal of General Microbiology 116, 99-110.

hartmanN, W., Tan, I., Hütterman, A. \& KÜhWEIN, H. (1977). Studies on the cell cycle of Myxobacter AL-I. II. Activities of seven enzymes during the cell cycle. Archives of Microbiology 114, 13-18.

Herbert, D., Phirps, P. J. \& Strange, R. E. (1971). Chemical analysis of microbial cells. Methods in Microbiology 5B, 209-344.

KоCH, A. L. (1978). Does the initiation of chromosome replication regulate cell division? Advances in Microbial Physiology 16, 49-98.

Koch, A. L. \& BlumberG, G. (1976). Distribution of bacteria in the velocity gradient centrifuge. Biophysical Journal 16, 389-405.

KOCH, A. L. \& SCHAECHTER, M. (1962). A model for statistics of the cell division process. Journal of General Microbiology 29, 435-454.

KuBITSCHEK, H. E. (1968). Linear cell growth in Escherichia coli. Biophysical Journal 8, 792-804.

KUBITSCHEK, H. E., BENDIGKEIT, H. E. \& L LOKEN, M. R. (1967). Onset of DNA synthesis during the cell cycle in chemostat cultures. Proceedings of the National Academy of Sciences of the United States of America 57, 1611-1617.

KUnG, F.-C. \& Glaser, D. A. (1977). Synchronization of Escherichia coli by zonal centrifugation. Applied and Environmental Microbiology 34, 328-329.

LLOYD, D. \& EDWARDS, S. W. (1977). Mitochondrial adenosine triphosphatase of the fission yeast Schizosaccharomyces pombe $972 \mathrm{~h}^{-}$. Changes in inhibitor sensitivities during the cell cycle indicate similarities and differences in binding sites. Biochemical Journal 162. 581-590.

LLOYD, D. \& POOLE, R. K. (1979). Subcellular fractionation: isolation and characterization of organelles. In Techniques in Metabolic Research, B202, pp. 1-27. Edited by H. L. Kornberg, J. C. Metcalfe, D. H. Northcote, C. I. Pogson \& K. F. Tipton. Amsterdam: Elsevier/North Holland Biomedical Press.

Lutkenhaus, J. F., Moore, B. A., Masters, M. \& DONACHIE, W. D. (1979). Individual proteins are synthesized continuously throughout the Escherichia coli cell cycle. Journal of Bacteriology 138, 352-360.

Mitchison, J. M. (1977). Enzyme synthesis during the cell cycle. In Cell Differentiation in Microorganisms, Plants and Animals, pp 377-401. Edited by L. Nover \& K. Mothes. Amsterdam: North-Holland Publishing Co.

Mitchison, J. M. \& Vincent, W. S. (1965). Preparation of synchronous cell cultures by sedimentation. Nature, London 205, 987-989. 
MOORE, C. L. (1971). Specific inhibition of mitochondrial $\mathrm{Ca}^{++}$transport by ruthenium red. Biochemical and Biophysical Research Communications 42, 298-305.

OHKI, M. \& MITSUI, H. (1974). Defective membrane synthesis in an E. coli mutant. Nature, London 252, 64-66.

PIRT, S. J. (1975). Principles of Microbe and Cell Cultivation, pp. 90-91. Oxford: Blackwell Scientific Publications.

Plank, L. D. \& Harvey, J. D. (1979). Generation time statistics of Escherichia coli B measured by synchronous culture techniques. Journal of General Microbiology 115, 69-77.

Pollack, M. S. \& Price, C. A. (1971). Equivolumetric gradients for zonal rotors: separation of ribosomes. Analytical Biochemistry 42, 38-47.

PoOLE, R. K. (1977a). Fluctuations in buoyant density during the cell cycle of Escherichia coli K12: significance for the preparation of synchronous cultures by age selection. Journal of General Microbiology 98, 177-186.

POOLE, R. K. (1977b). The influence of growth substrate and capacity for oxidative phosphorylation on respiratory oscillations in synchronous cultures of Escherichia coli K12. Journal of General Microbiology 99, 369-377.

Poole, R. K. (1980). Temporal diversity of bacterial respiratory systems. Membrane and respiratory development during the cell cycle. In Diversity of Bacterial Respiratory Systems, (in the Press). Edited by C. J. Knowles. Boca Raton, Fla: CRC Press.
POOle, R. K., Lloyd, D. \& KeMP, R. B. (1973). Respiratory oscillations and heat evolution? in synchronously-dividing cultures of the fission yeast Schizosaccharomyces pombe. Journal of General Microbiology 77, 209-220.

Poole, R. K., Waring, A. J. \& Chance, B. (1979). The reaction of cytochrome $o$ in Escherichia coli with oxygen. Low temperature kinetic and spectral studies. Biochemical Journal 184, 379-389.

RoBinson, J.D.(1976). (Ca + Mg)-stimulated ATPase activity of a rat brain microsomal preparation. Archives of Biochemistry and Biophysics 176, 366-374.

SaRGENT, M. G. (1973). Membrane synthesis in synchronous cultures of Bacillus subtilis 168 . Journal of Bacteriology 116, 397-409.

SCHERR, F. \& GÜNTHER, T. (1978). Inhibition of $\mathrm{Mg}, \mathrm{Ca}-\mathrm{ATPase}$ from $E$. coli by ruthenium red. Zeitschrift für Naturforschung 33c, 61-64.

TsuchiYA, T. \& Rosen, B. P. (1975). Energy transduction in Escherichia coli. The role of the $\mathrm{Mg}^{2+}$ ATPase. Journal of Biological Chemistry 250, 8409-8415.

Williams, F. M. (1971). Dynamics of microbial populations. In Systems Analysis and Simulation in Ecology, vol. 1, pp. 197-267. Edited by B. C. Patten. New York \& London: Academic Press.

Wraight, C. A., Lueking, D. R., Fraley, R. T. \& KAPLAN, S. (1978). Synthesis of photopigments and electron transport components in synchronous phototrophic cultures of Rhodopseudomonas sphaeroides. Journal of Biological Chemistry 253, 465-471. 